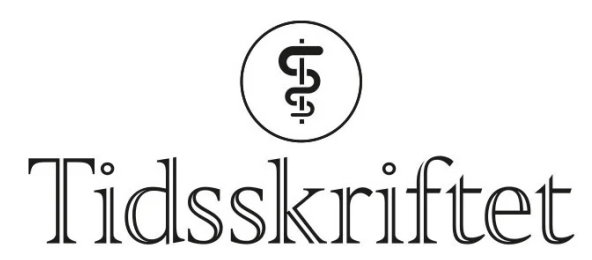

DEN NORSKE LEGEFORENING

\title{
For identifikasjon av sopp på laboratoriet
}

\author{
ANMELDELSER
}

\section{CECILIE TORP ANDERSEN}

Oslo universitetssykehus, Rikshospitalet

Avdeling for mikrobiologi

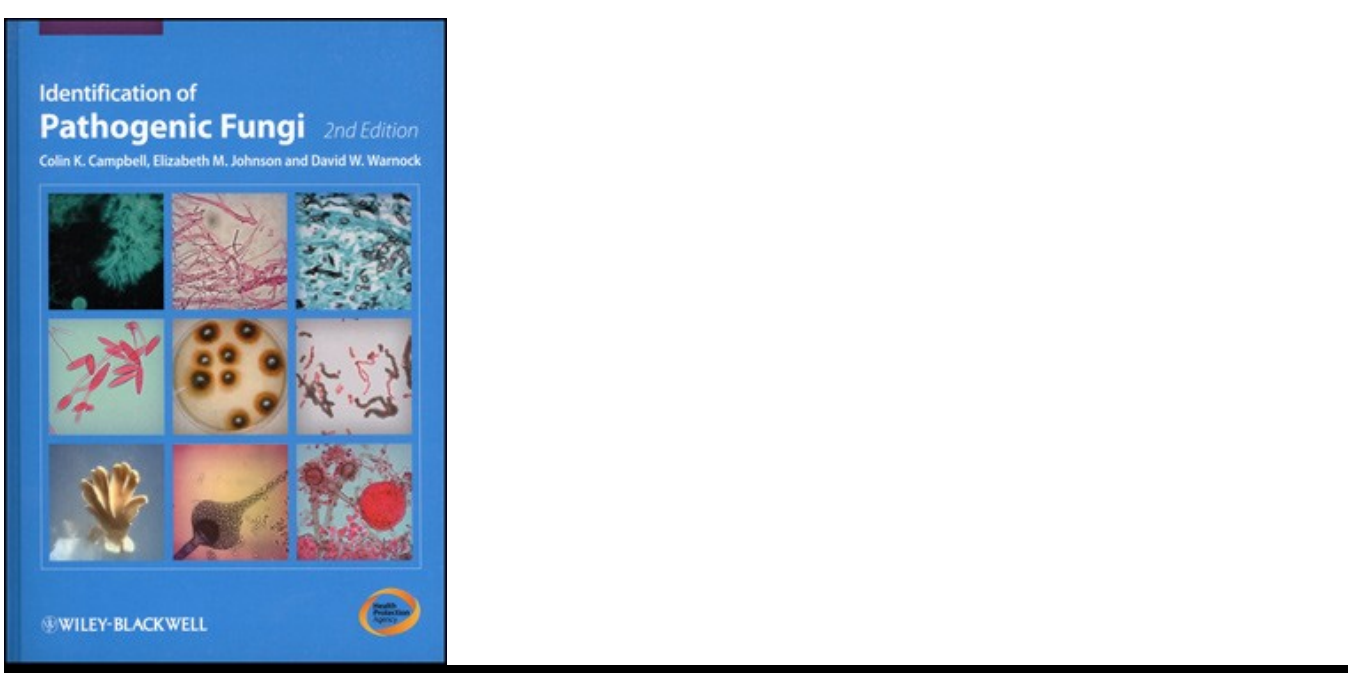

Campbell, Colin K.

Johnson, Elizabeth M.

Warnock, David W.

Identification of pathogenic fungi

2. utg. 337 s, tab, ill. Chichester: Wiley-Blackwell, 2013. Pris GBP go

ISBN 978-1-4443-3070-0

Den mikrobiologiske diagnostikken ved soppinfeksjoner baser seg fortsatt i stor grad på dyrking, direkte mikroskopi og histopatologi. I denne boken gir forfatterne en kortfattet og systematisk tilnærming til medisinsk mykologi med fokus på tradisjonell identifikasjon av de vanligste agens som gir klinisk sykdom hos mennesker og fungerer som en praktisk 
nøkkel til identifikasjon av disse. Målgruppen er ulike yrkesgrupper i mikrobiologiske laboratorier i sykehus, men boken vil også kunne være av interesse for patologer, forskere og andre innen fagfeltet mykologi utenfor human medisin.

Forfatterne har bakgrunn fra Health Protection Agencys referanselaboratorium i mykologi i Bristol og fra CDCs National Center for Emerging and Zoonotic Infectious Diseases. Første utgave fra 1996 er nå revidert og utvidet med et rikt utvalg bilder og et eget kapittel om påvisning av sopp i vev og kroppsvæsker med en praktisk nøkkel til identifikasjon, basert på morfologi i snitt, i tillegg til et rikt bildemateriale av histopatologi og direkte mikroskopi av prøvematerialet av de hyppigst forekommende agens.

Boken er systematisk oppbygd med introduksjon og kortfattet oversikt over generell mykologi, etterfulgt av identifikasjon av muggsopp og gjærsopp. Totalt omtales over 100 ulike agens som kan være årsak til sykdom hos mennesker. Gjærsopp omtales i et eget kapittel, med hovedvekt på morfologi og biokjemiske tester. Kromogene medier og resistensbestemmelse beskrives bare kort. Muggsoppkapitlene inneholder nøkkel til identifikasjon med utgangspunkt i mikroskopisk morfologi av kultur. Identifikasjon av dermatofytter, som er filamentøse sopparter som muggsoppene, får også grundig omtale. De ulike spesies beskrives systematisk med kort beskrivelse av klinisk betydning og differensialdiagnoser. Omtalene suppleres med bilder av kolonier og mikroskopi og, som i tidligere utgave, gode skjematiske tegninger.

Dette er ingen lærebok i mykologi, men som tittelen tilsier et nyttig verktøy for identifikasjon av sopp og hjelp til vurdering av betydning av funnet. Forfatterne har ikke beskrevet nyere metoder innen molekylær mikrobiologi som PCR og sekvensering, men angir når dette er nyttig for identifisering av agens og når det er påkrevet for endelig identifikasjon. Massespekterbasert teknologi (Maldi-TOF MS) er ikke omtalt.

Invasive soppinfeksjoner i Norge domineres av candida med en absolutt dominans av Candida albicans-infeksjoner. Invasive muggsoppinfeksjoner er sjeldne og forårsakes vanligvis av Aspergillus fumigatus. Men også i Norge ser vi infeksjoner som kryptokokkose, zygomykoser og infeksjoner med dimorf sopp. Korrekt identifikasjon av sopp er essensielt for valg av behandling. Ved hjelp av en bok som denne kan man gjøre tentativ identifikasjon også av sjeldne agens og dermed raskere rettlede klinikere i påvente av endelig identifikasjon og resistensbestemmelse.

Publisert: 12. november 2013. Tidsskr Nor Legeforen. DOI: 10.4045/tidsskr.13.1057

(C) Tidsskrift for Den norske legeforening 2023. Lastet ned fra tidsskriftet.no 26. april 2023. 